This article has been scanned by iThenticat No plagiarism detected

Volume 3, Issue 3, June 2021

p. $215-225$

\title{
AL-GHAZALI, HIS EDUCATIONAL AND MORAL OPINION THROUGH HIS SUFI SCHOOL(450-505 AH / 1058-1111 AD)
}

http://dx.doi.org/10.47832/2757-5403.3-3.21

Sahar Mahdi AHMED ${ }^{1}$

\begin{abstract}
:
Al-Ghazali is one of the most famous characters of the fifth century AH /Eleventh century $\mathrm{AD}$, He was called by many titles, including the Hujjat Al-Islam, Philosopher, Speaker, Sufi, and Shafi'i, He is considered one of the flags of islamic thought, and the most influential of his era until the present time, He left a deep impact in various fields of knowledge through his various books.

The research presented education and ethics through it is study and it is relationship to islamic curriculum and teaching. And since islam came to correct and support morals and education through the noble verses presented by the Holy Qur'an urging the noble islamic morals. And the great prophet ( peace be upon him ) provided a good model and example for muslims in particular, And for humanity in general.

On this basis, We preferred that the definition of Al-Ghazali's moral and educational views and his approach to this context be made through his sufi school.
\end{abstract}

Key words: Al-Ghazali, Education, Moral, Sufism.

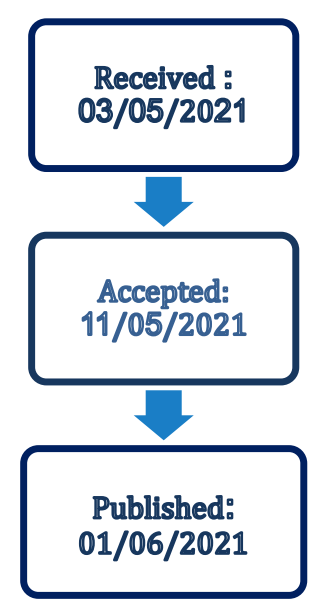

\footnotetext{
${ }^{1}$ Dr. , Basrah University, Iraq, saharalnagafi702@gmail.com, https://orcid.org/0000-0002-5777-3851
} 


\title{
الغزالي وأراءه التربوية والأخلاقية من خلال مدرسته الصوفية (505-450)
}

\author{
2
}

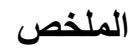

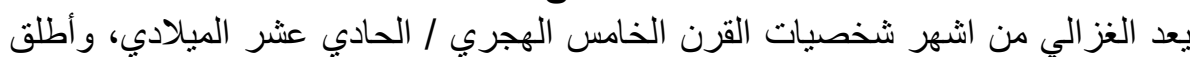

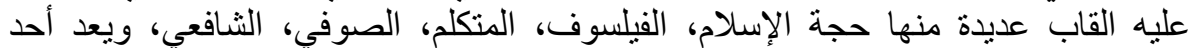

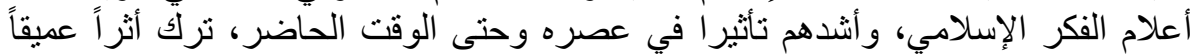

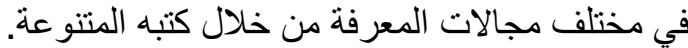
عرض البحث التربية والأخلاق من خلال دراستها و وعلاقتها بالمنهج والتهات التعاليم الإسلامية،

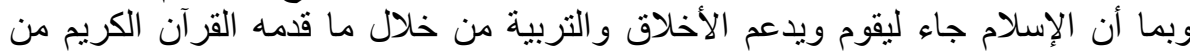

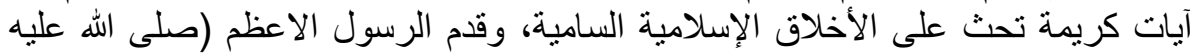

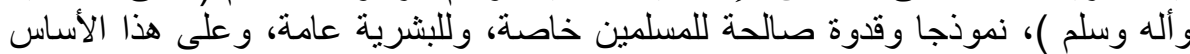

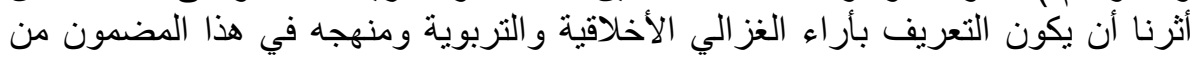

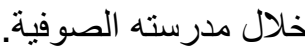
الكلمات المفتاحية: الغزالي، التربية، الأخلاق، الصوفية.
\end{abstract}

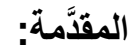

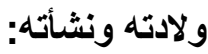
هو ابو حامد محمد بن محمد بن أحمد الغزالي الطوسي (1)، الثنافي الثعي صاحب التصانيف حجة الإسلام (2). و الغزالي

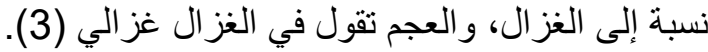

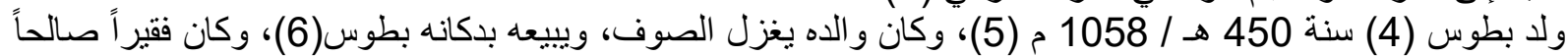

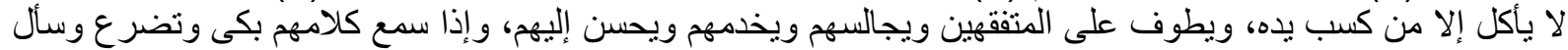

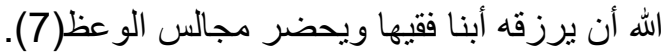

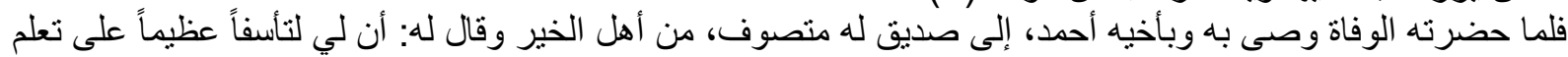

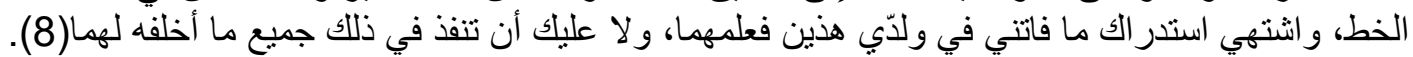

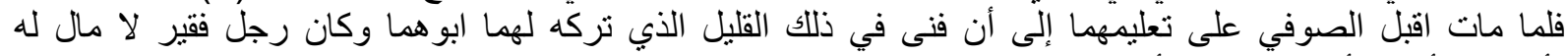

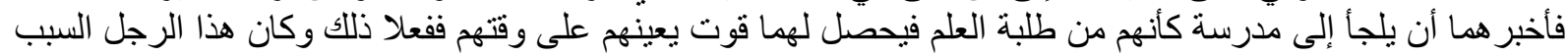

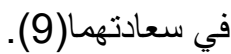

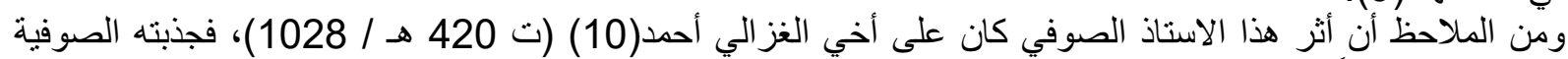

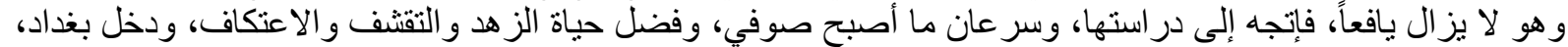

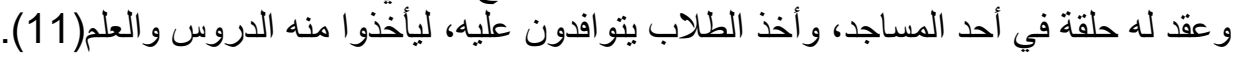

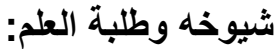
بعد التطرق إلى حياته ونشأته وكيف اهتم ابوه بتعليهه على الر غم من الفقر الذي كان بعانيه، نرى أن الغز الي واخوه اهتما

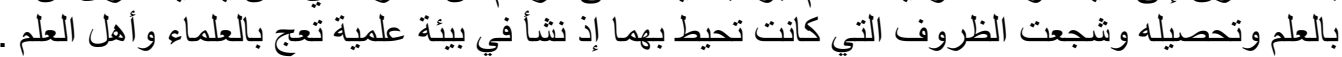

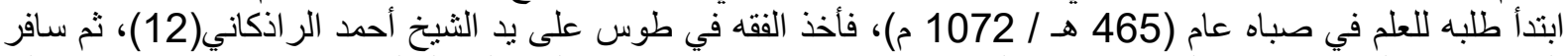

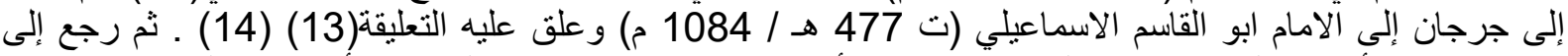

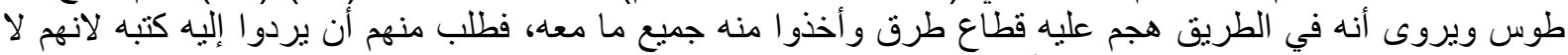

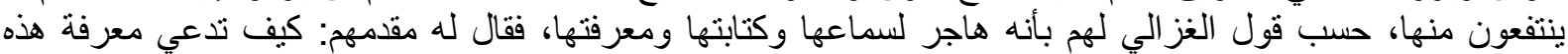


العلوم، وقد أخذتها منك فتجردت منها وبقيت بلا علم، وأمر رئيس قطاع الطرق برد التعليقة إلى الغزالي(15). هذه الئه

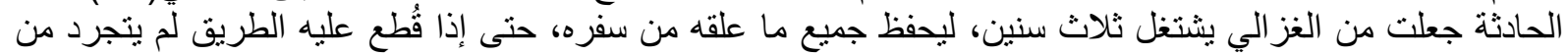

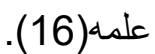

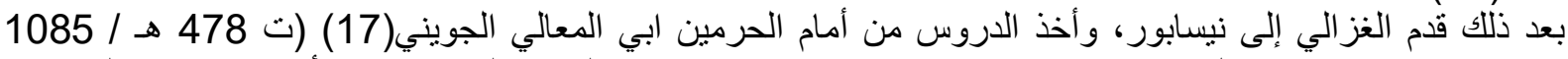

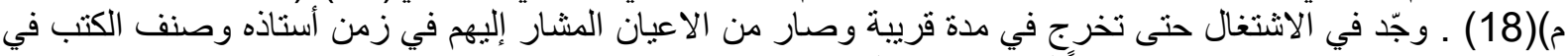

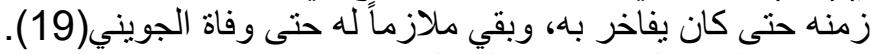

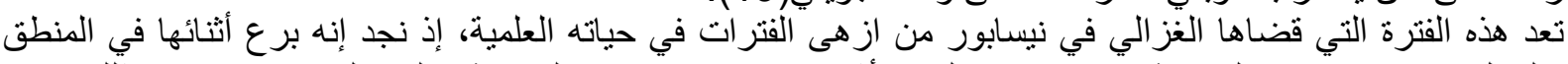

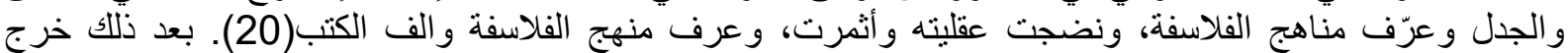

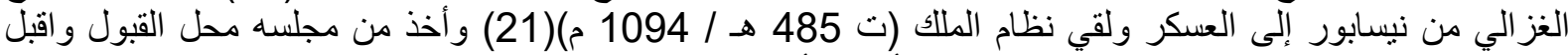

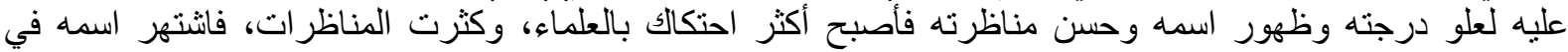

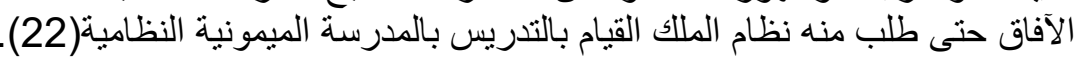

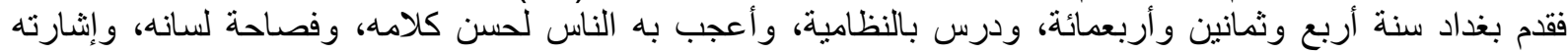

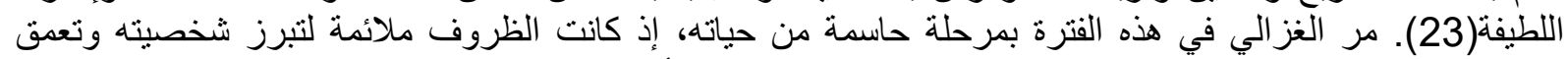

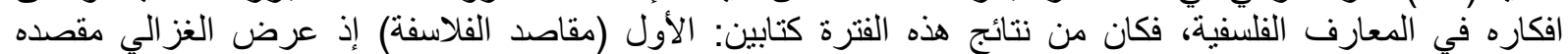

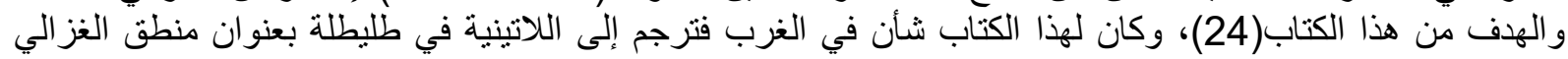

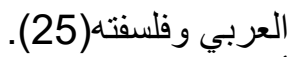

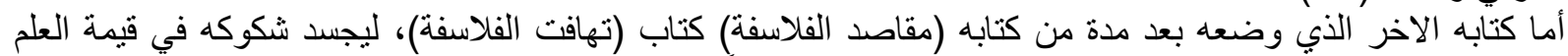

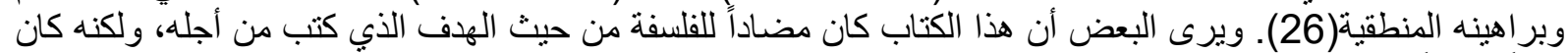

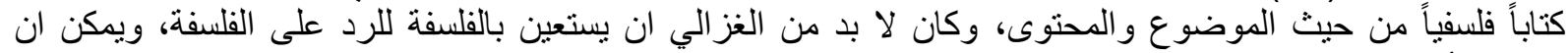

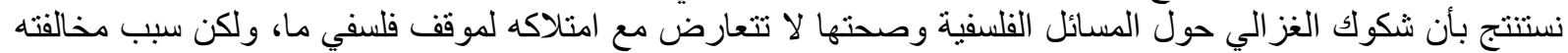

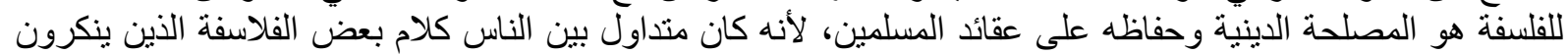

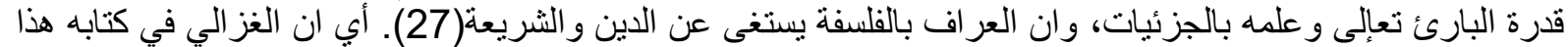

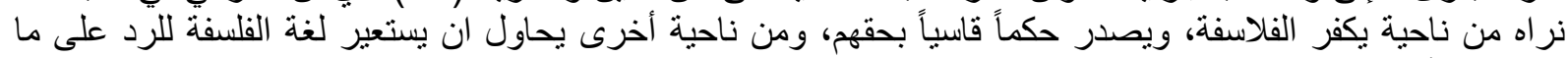

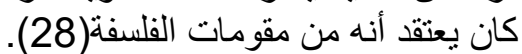

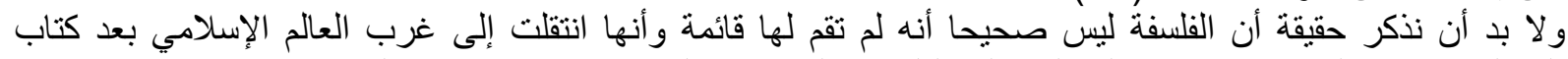

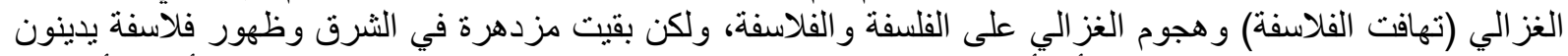

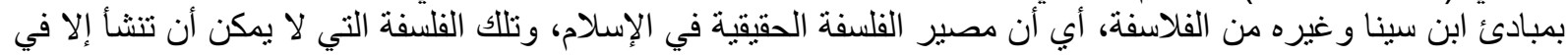

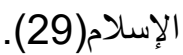

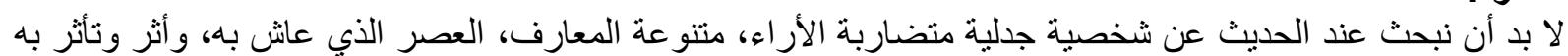

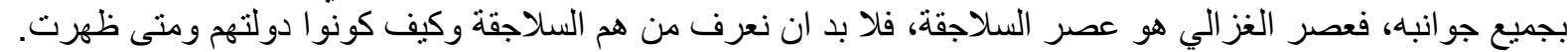

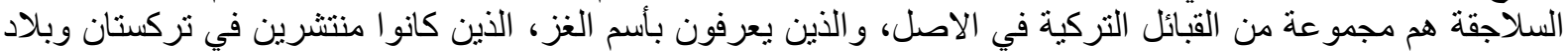

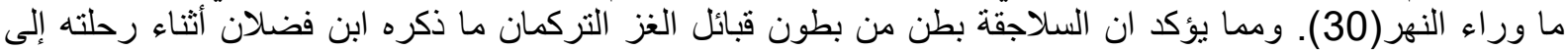

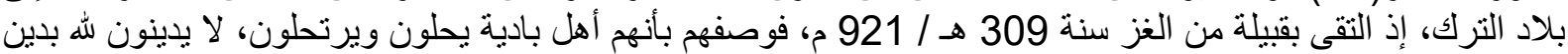

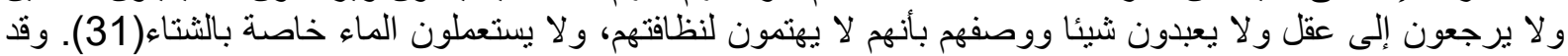

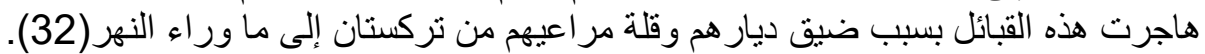

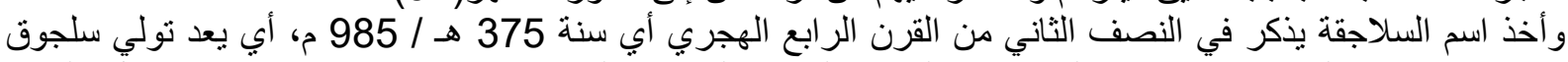

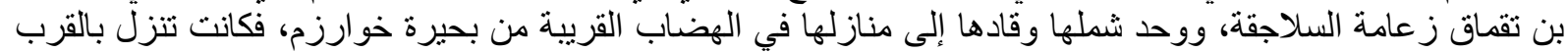

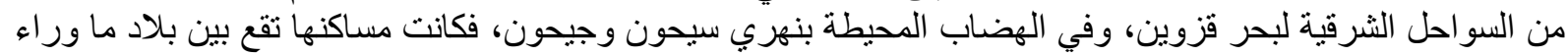

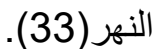
بدأوا يظهرون على على مسرح الاحداث التاريخية بعد ان دخلو ا بسلسلة من المعارك مع الدولة الغزنوية وتوسعهم في خر اسان

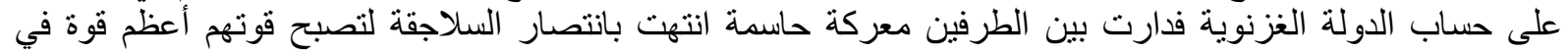

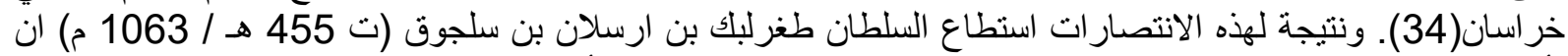

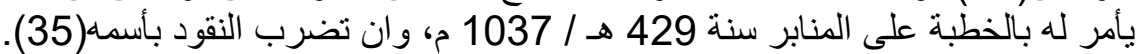

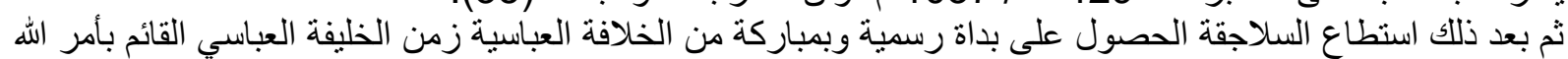

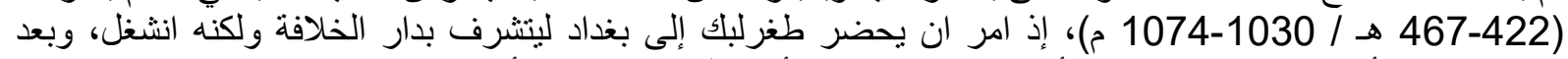

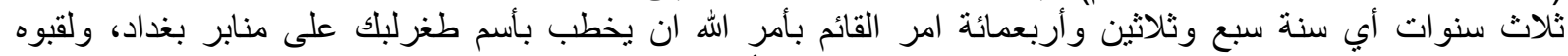

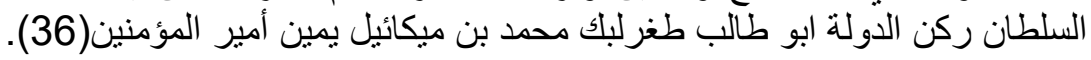




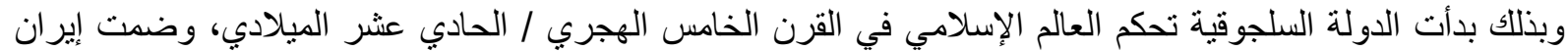

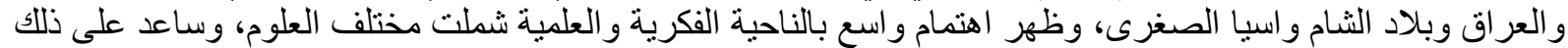

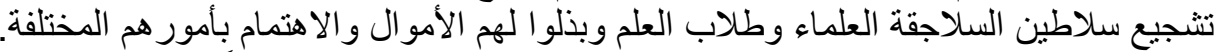

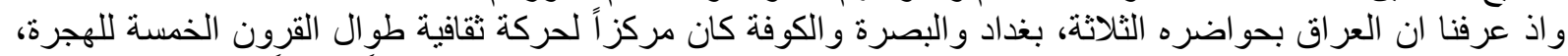

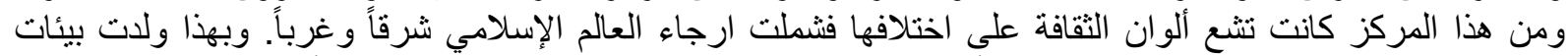

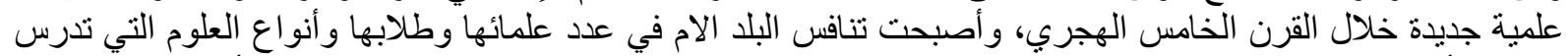

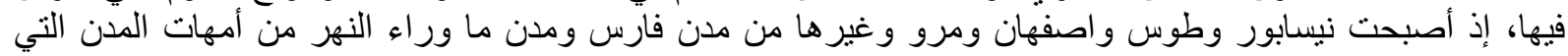

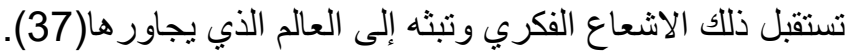

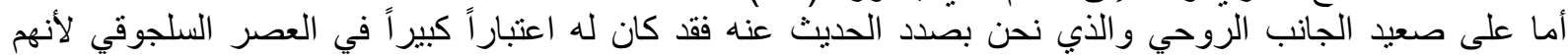

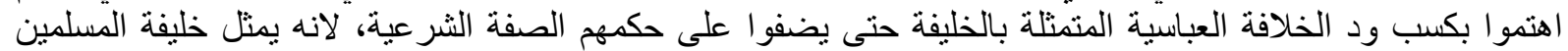

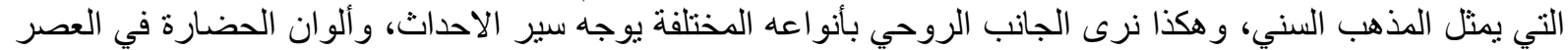

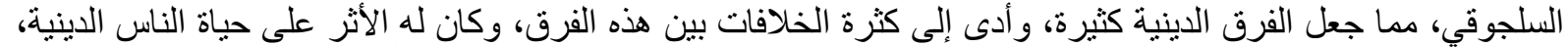

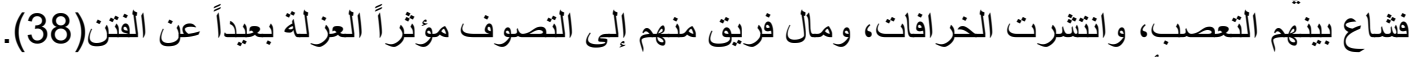

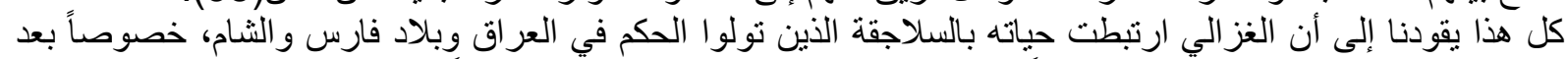

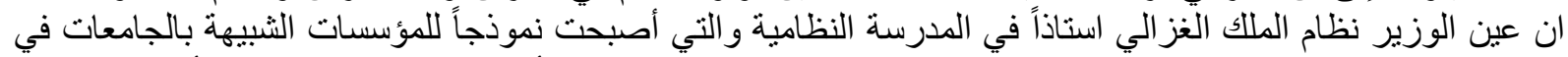

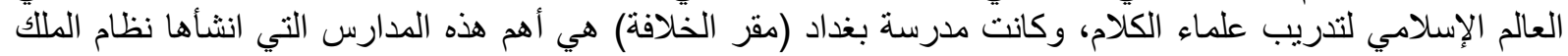

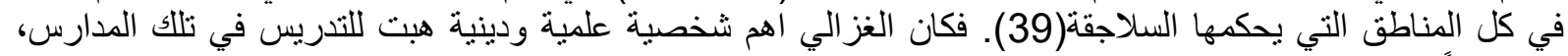

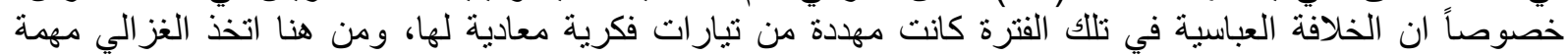

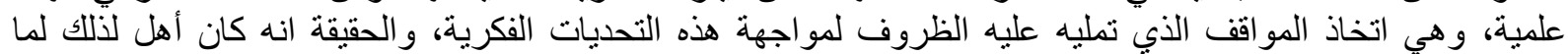

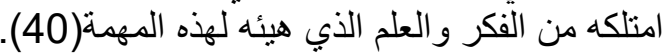

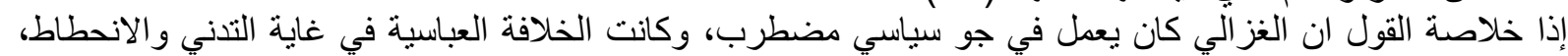

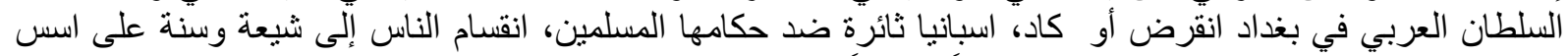

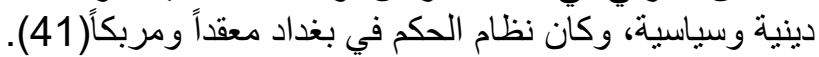

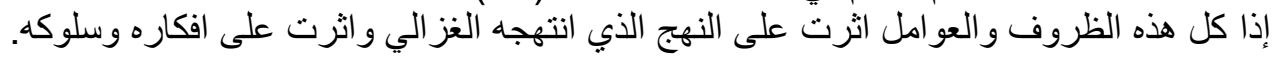

رحلاته العلمية:

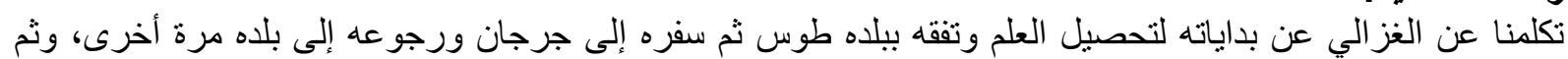

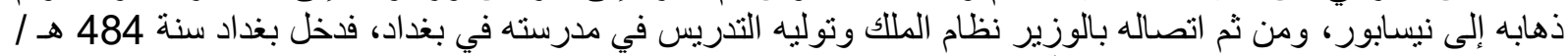

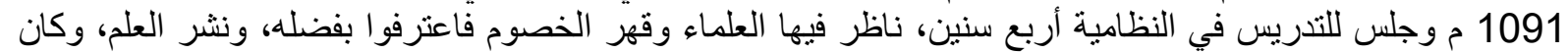

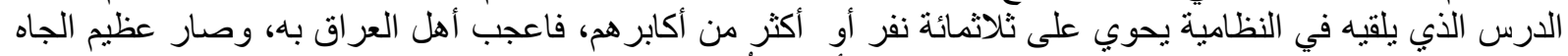

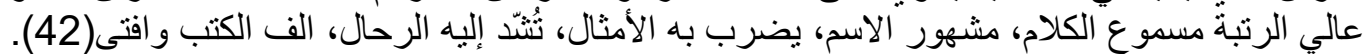

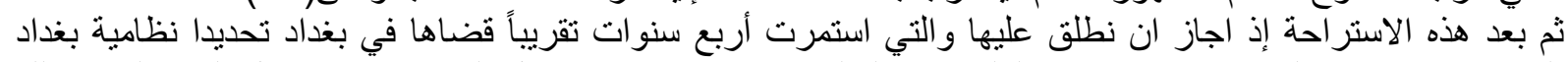

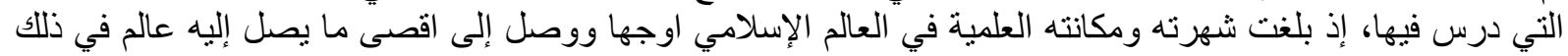

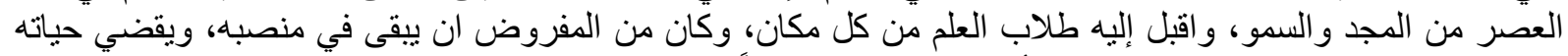

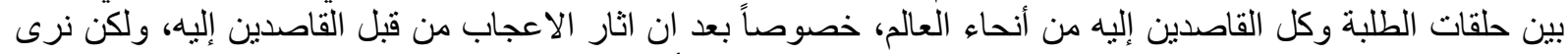

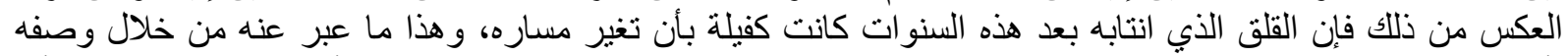

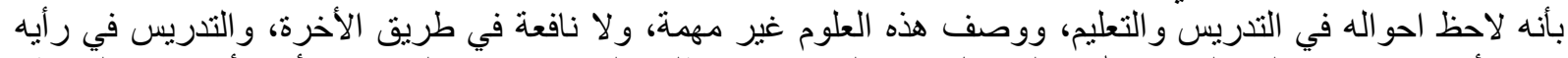

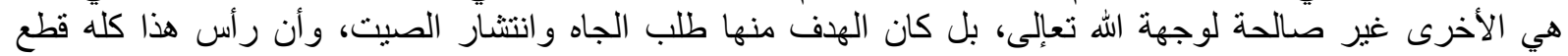

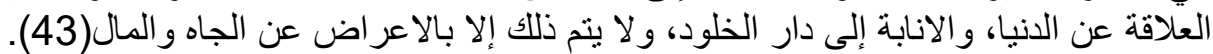

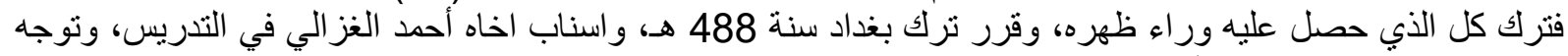
إلى الحج(44) لزيارة بيت الله الحر ام(45).

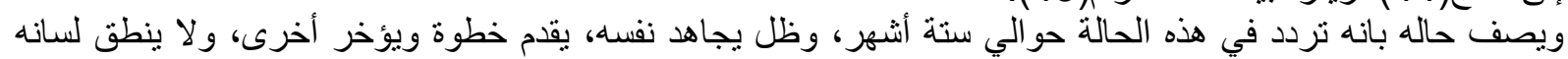

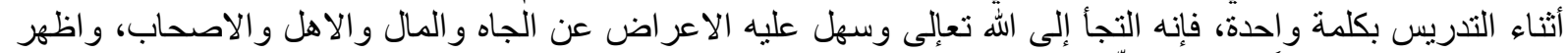

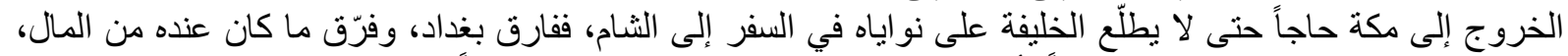

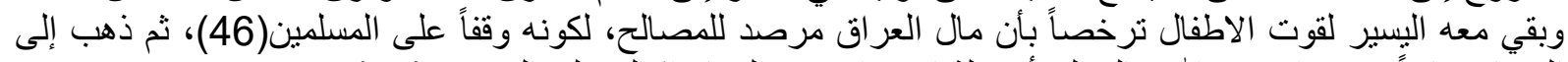

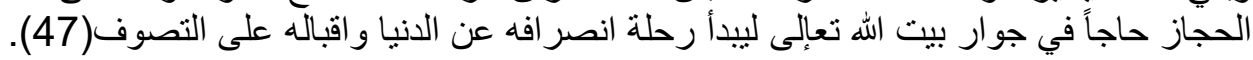


ودرس في المدرسة الغزالية(48) في دمشق ثم دخل دمشق سنة تسع وثمانين واربمعمائة للهجرة، ثم توجه إلى بيت

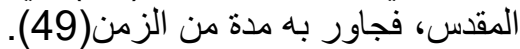

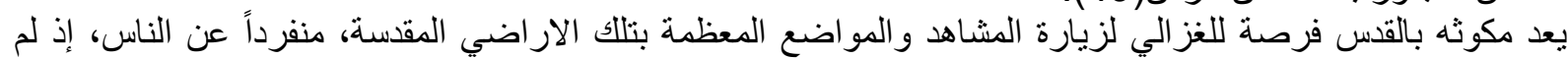

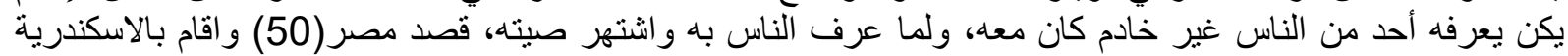

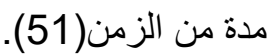

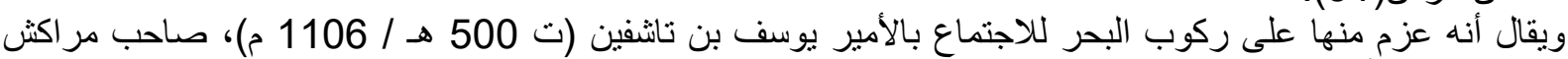

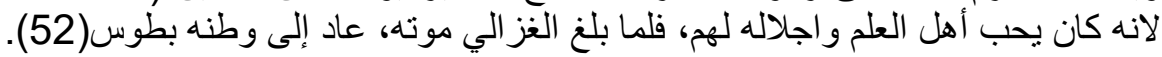

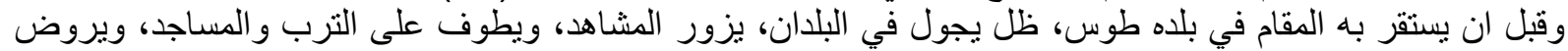

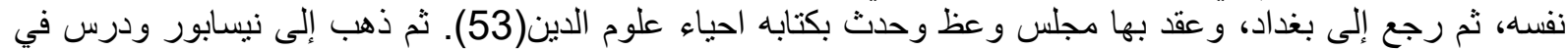

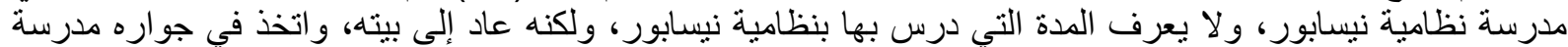

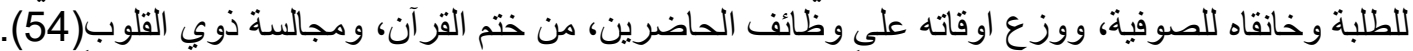

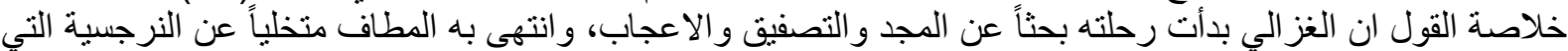
لازمته لانها في اعتقاده كانت تقف حاجزاً بينه وبين طريق الله، والفهم الصحيح لحياة دينية خالصة خالية من الرياء

أراءه التربوية والأخلاقية من خلال مدرسته الصوفية:

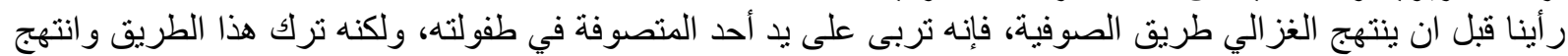

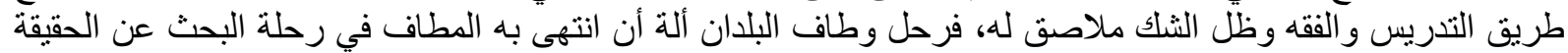

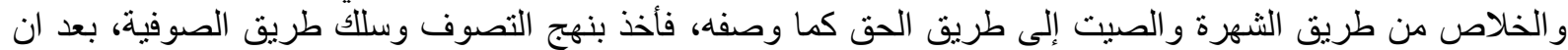

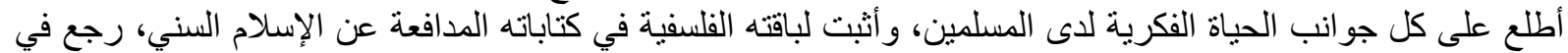

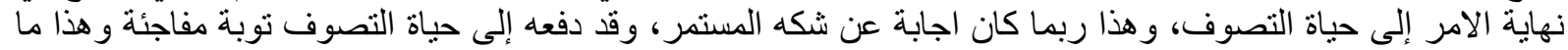

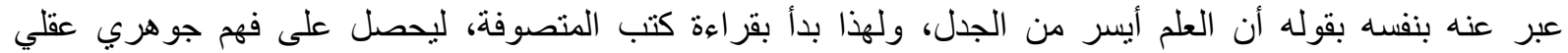

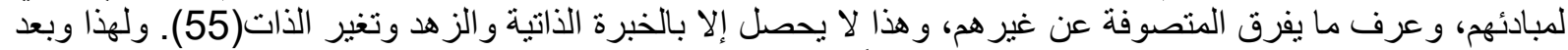

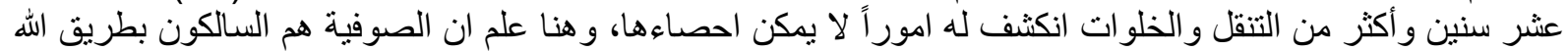

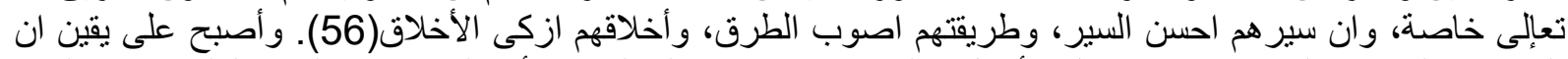

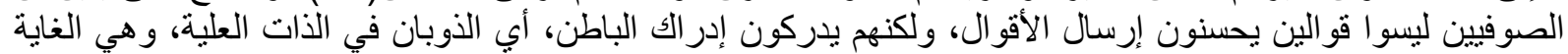

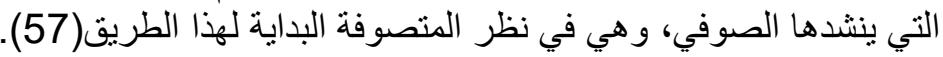

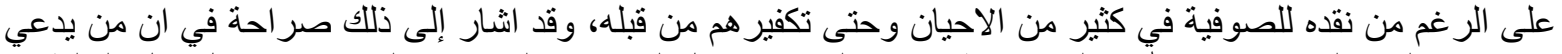

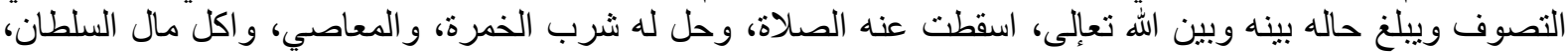

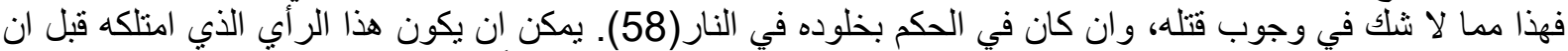

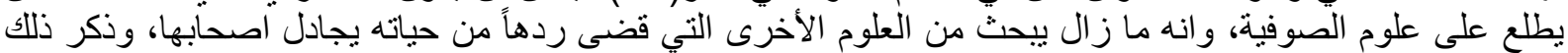

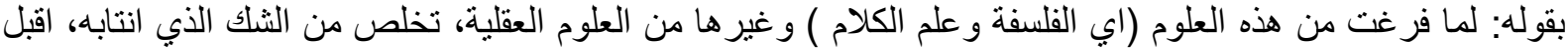

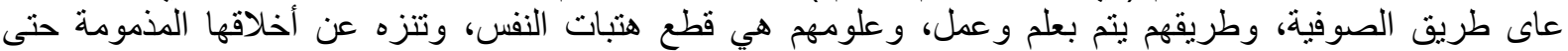

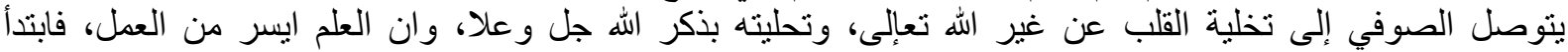

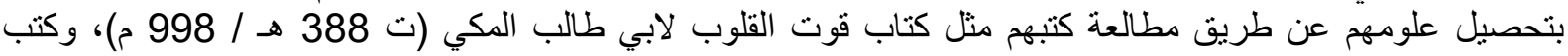

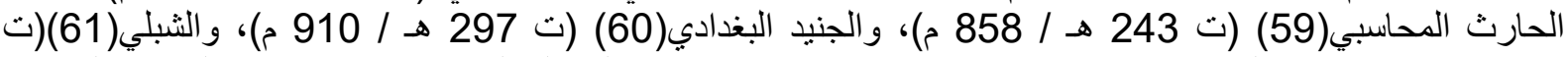

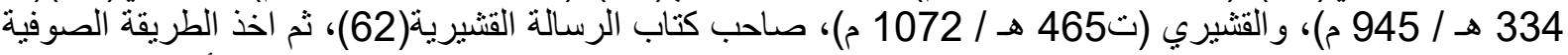

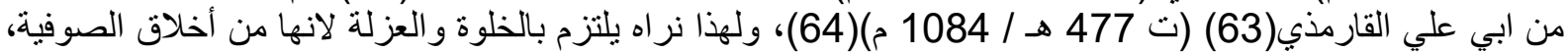

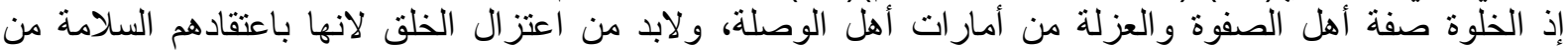

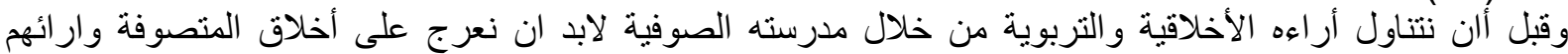

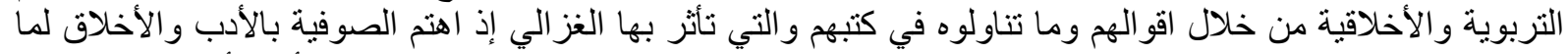

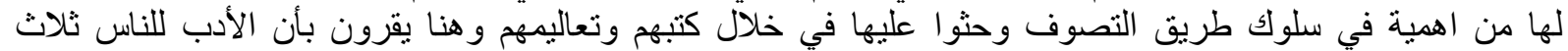

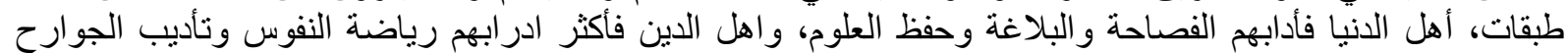

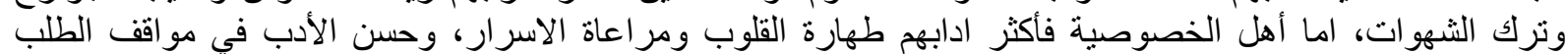

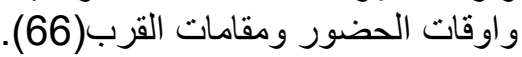

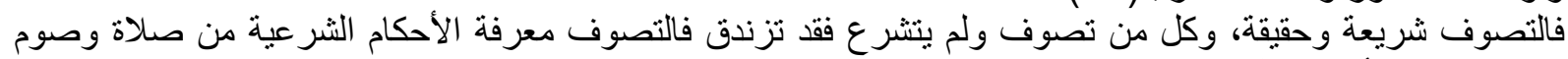

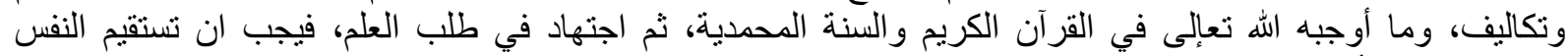

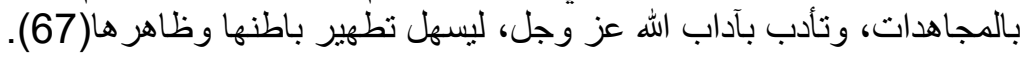




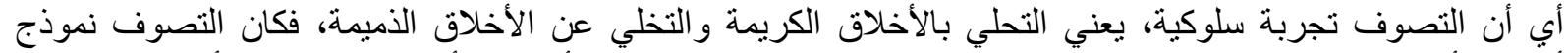

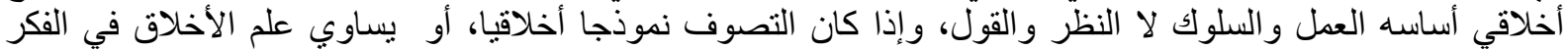

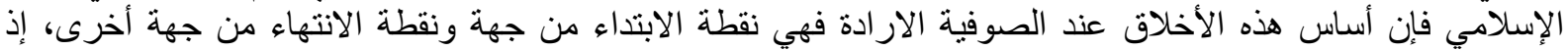

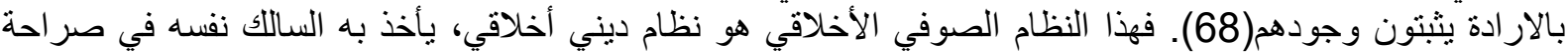

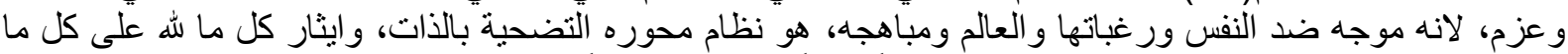

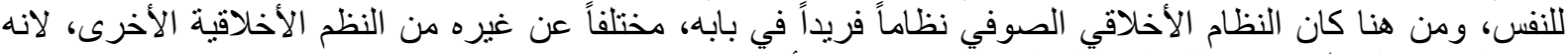

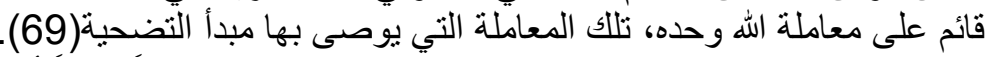

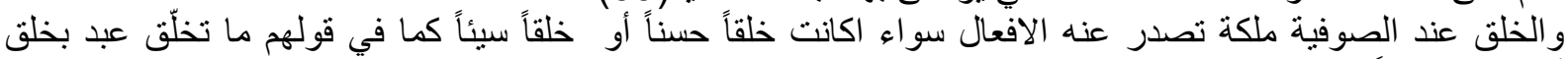

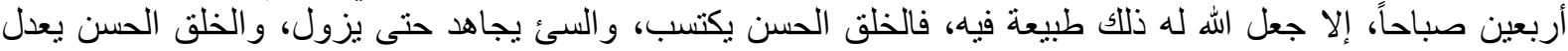

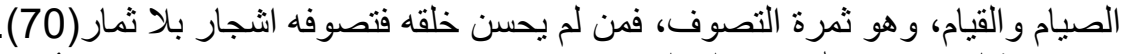

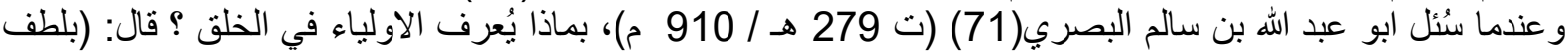

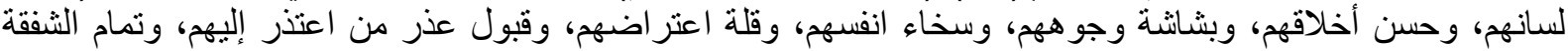
على جميع الخلائق، برهم وفالهن وفاجر هم)(72).

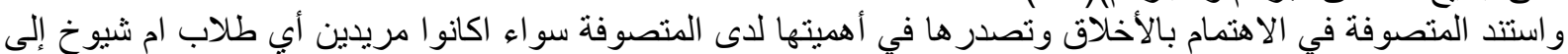

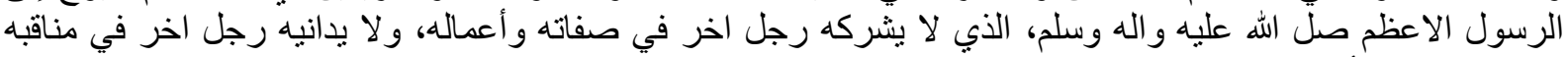

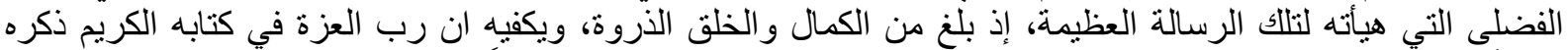

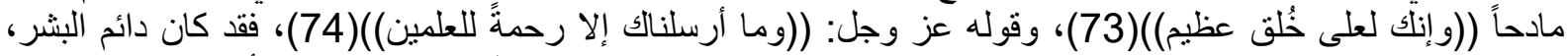

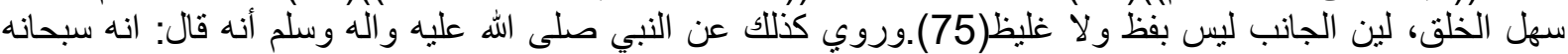

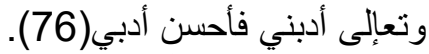

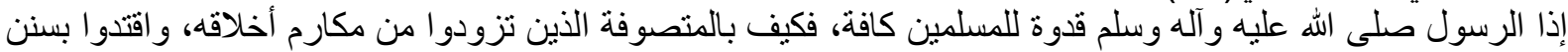
شر ائعه، و اذ كان القرآن الكريم وصف خاتم الانبياء والرسل في كثير فئ من الإيات الكريمة بالخلق العظيم و القويم، فلم يدانيه

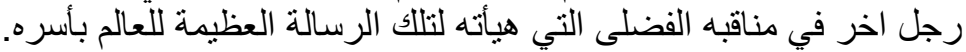

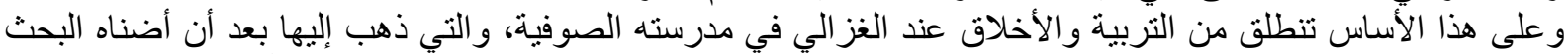

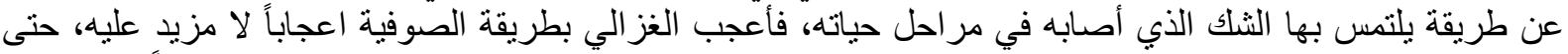

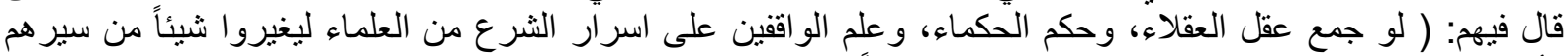

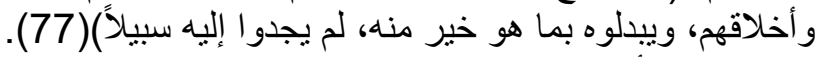

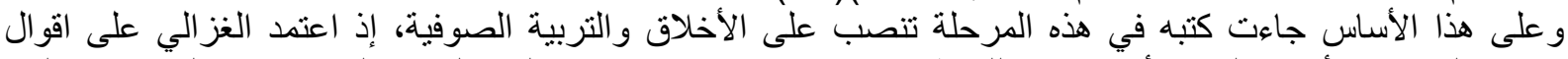

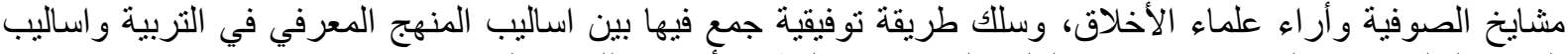

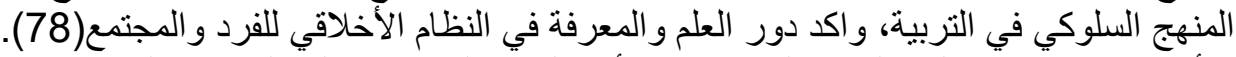

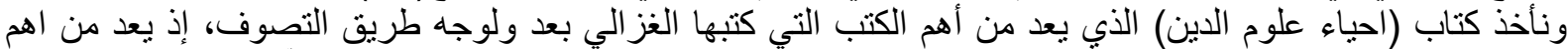

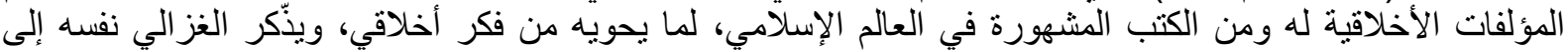

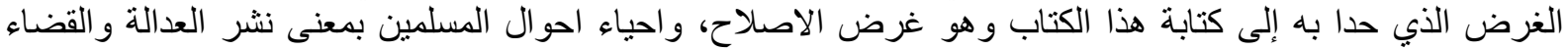

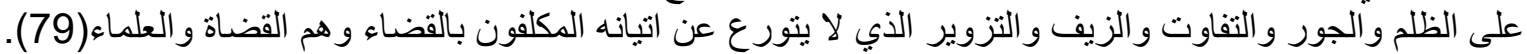

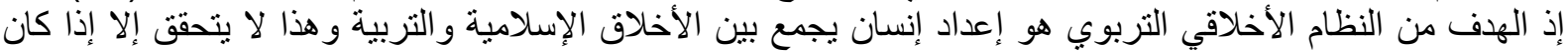

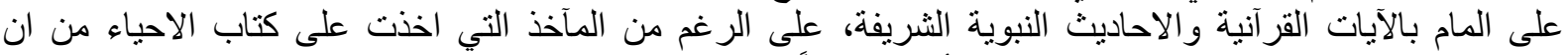

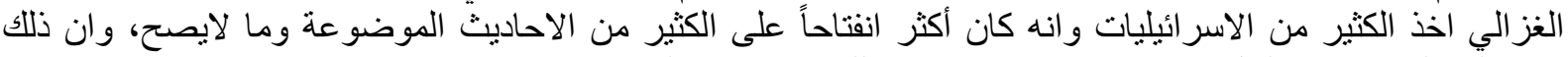

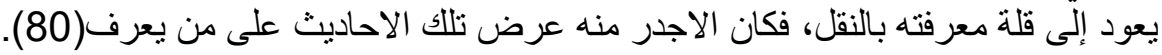

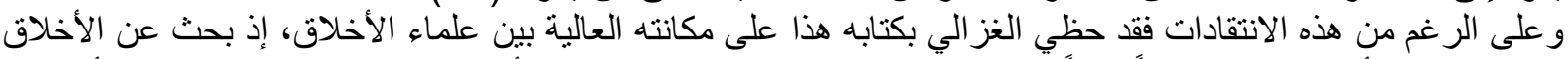

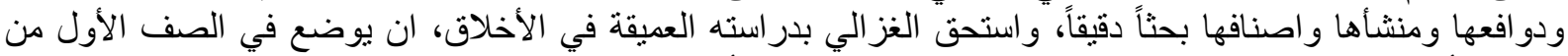

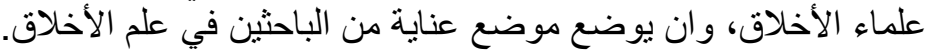

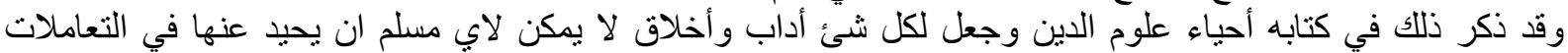

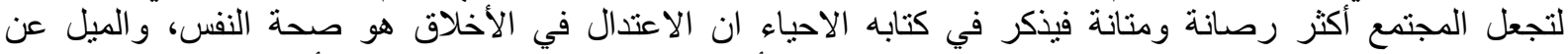

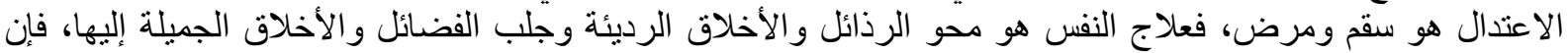

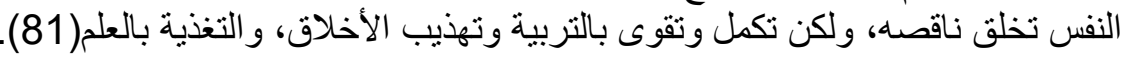




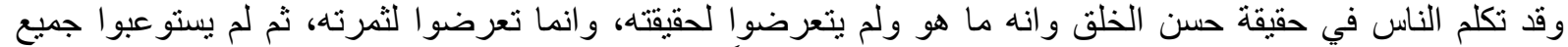

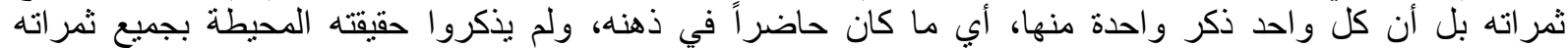

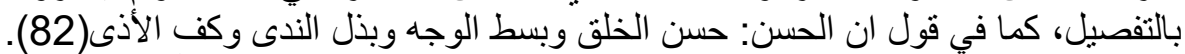

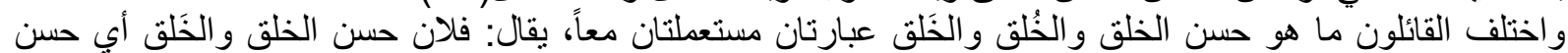

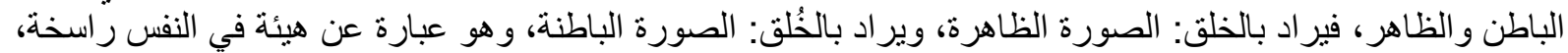

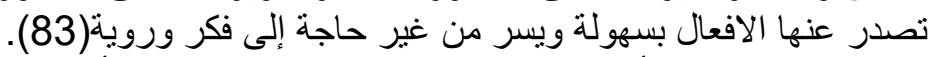

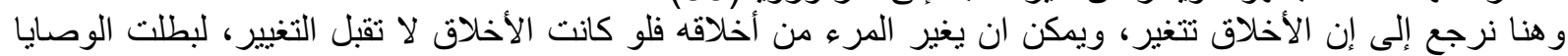

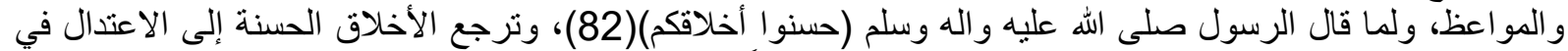

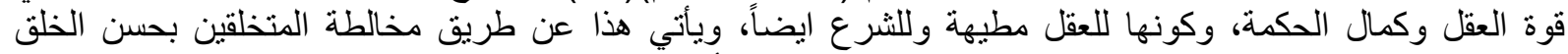

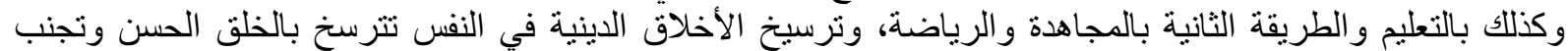

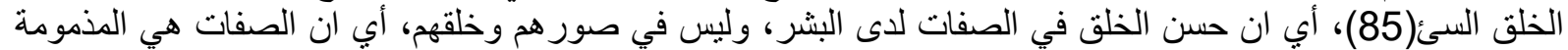

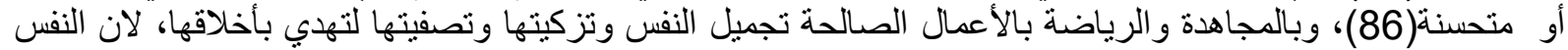

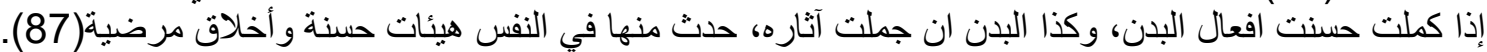

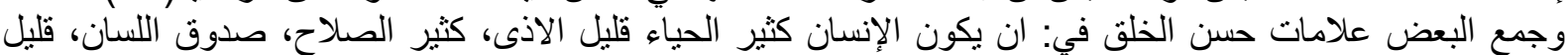

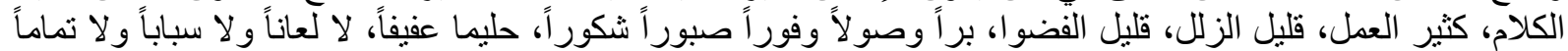

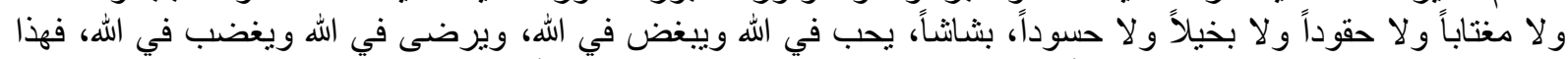

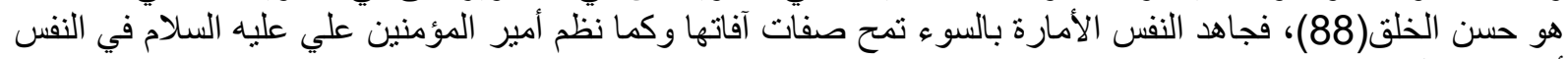

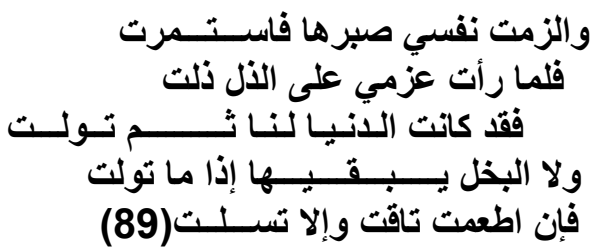

$$
\begin{aligned}
& \text { صبرت عن اللاتات حتى تولت } \\
& \text { أبيات من الثعر وهي: } \\
& \text { وكاتت على الايام نفسي عزيزة }
\end{aligned}
$$

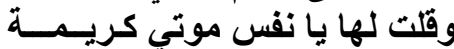

$$
\begin{aligned}
& \text { فلا الجود يغنيها إذا هي أقبلت } \\
& \text { وما النفس إلا حيث يجعلها الإنها }
\end{aligned}
$$

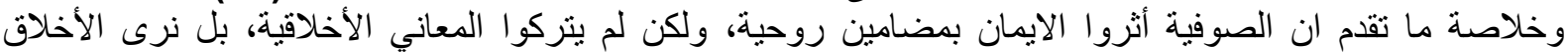

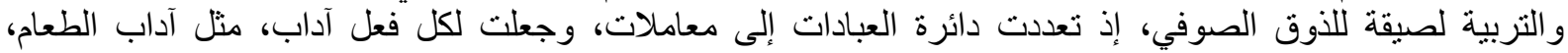

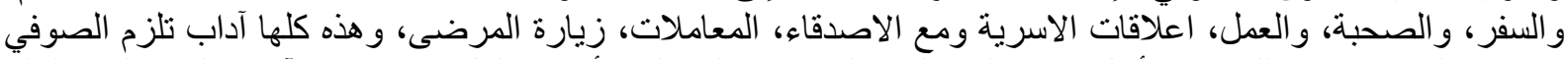

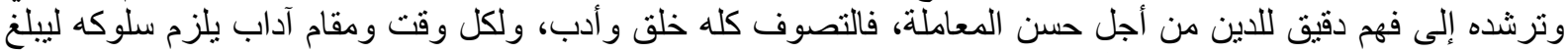
الصوفي اسمى منزلة ودرجة عند للاين عن الله عز وجل.

توفي الغز الي سنة 505 هـ / 1111 م(90)، بعد ان لزم الانقطاع، ووظف أوقاته على أعمال الخير، وكانت وفاته

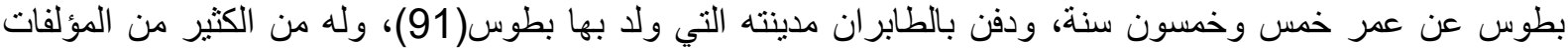

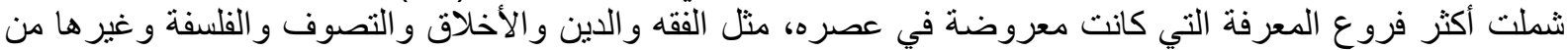

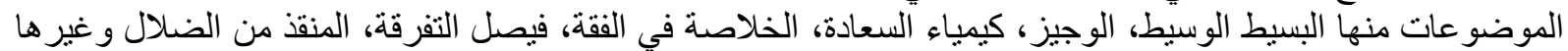

من المصنفات التي يقال انها قاربت الف مصنف البيز، كيناء إلا واحدادة(92).

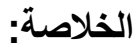

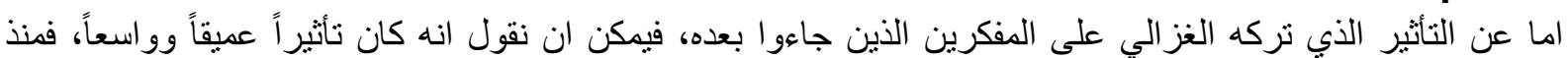

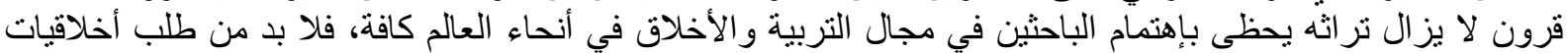

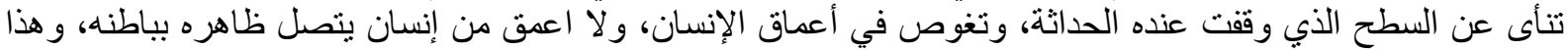

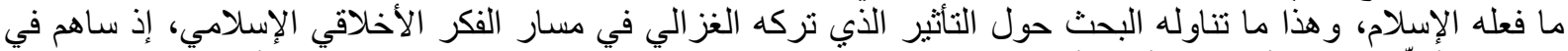

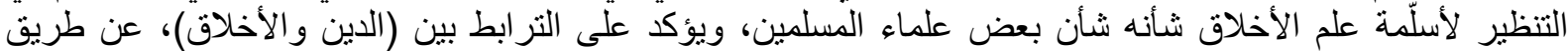

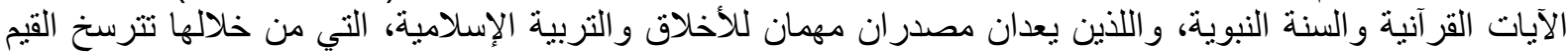
السامية في الدجتمع ليصل إلى الكمال و التقدم. 
1967، المنقذ من الضلال و الموصل إلى ذي العزة و الجلال، حققه وقدم له/د.صليبا جميل ود.كامل عباد، ط/7، بيروت، دار الاندلس للطباعة و النشر.

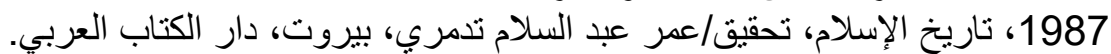

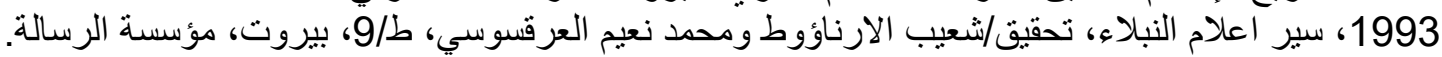

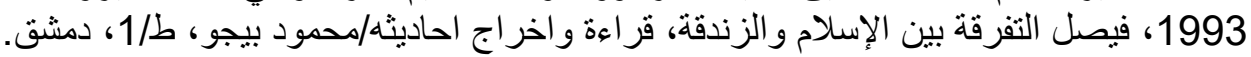

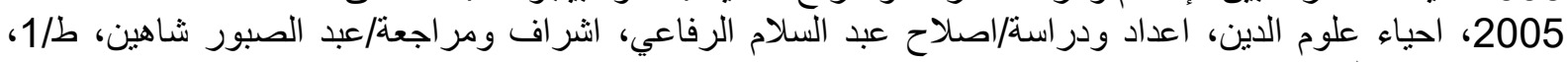

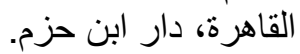

ابن الاثير، ابي الحسن علي بن ابي مكرم الثيياني (ت 630 هـ / / 630 هـ 1233م)، 1987، الكامل في التاريخ، مر اجعة/محمد

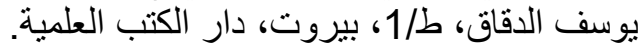

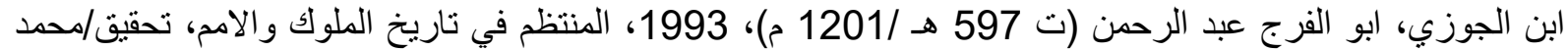

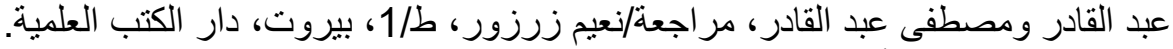

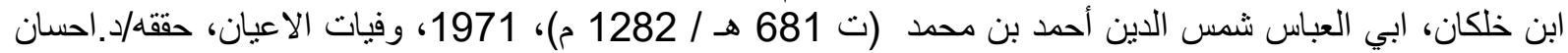

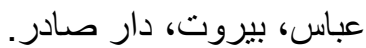

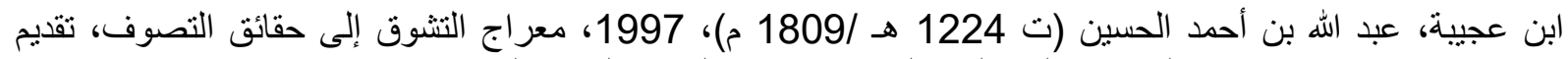

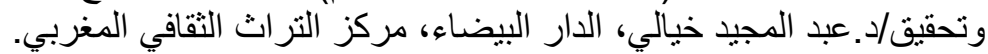

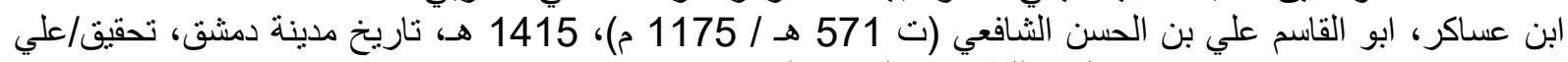

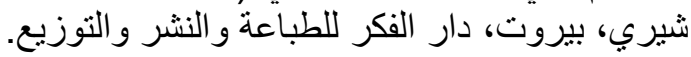

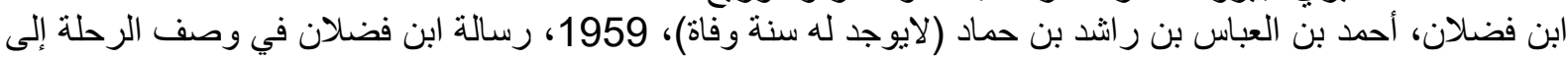

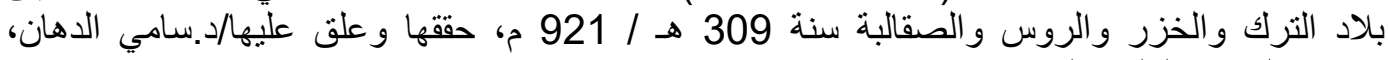
دمثق، المجمع العلمي العربي.

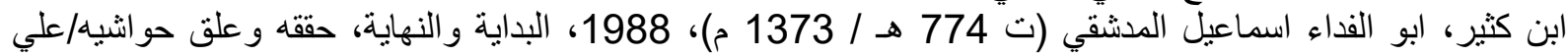

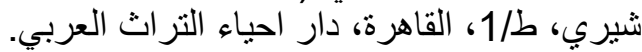

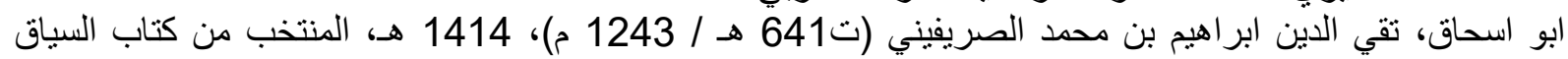

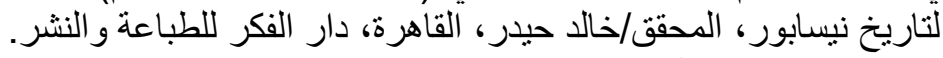

بلات، سر العالمين وكثثف ما في الدارين، بلام.

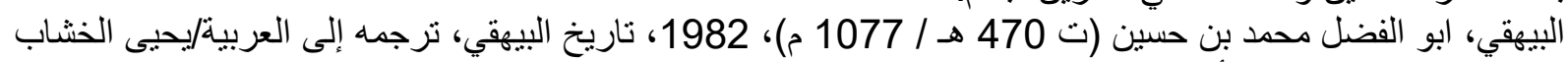
وصادق نشأت، بيروت، دار النهضية العربية.

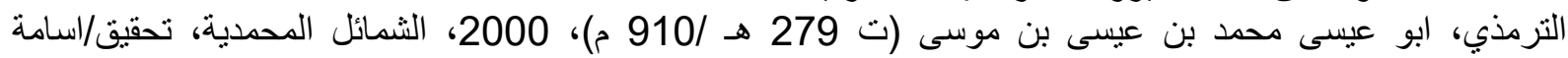

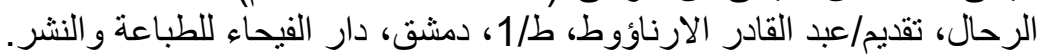

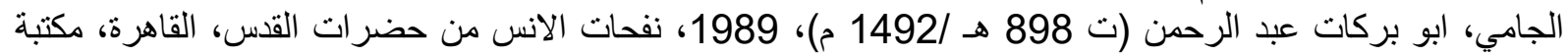

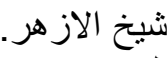

الذهبي، شمس الدين محمد بن أحمد بن عثمان (ت 748 هـ /645 / 1349 م) .

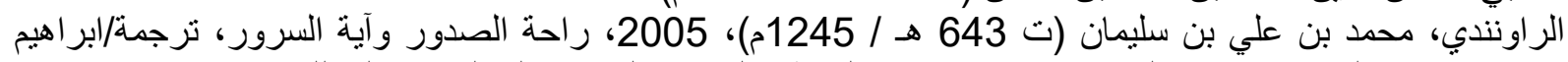

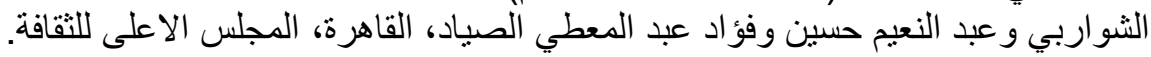

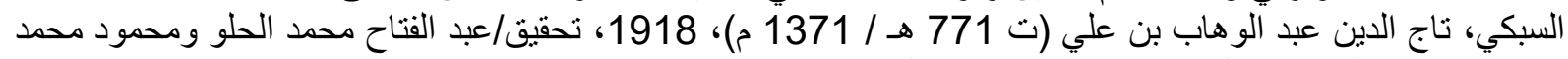
الطناحي، القاهرة، دار أحياء الكتب العربية.

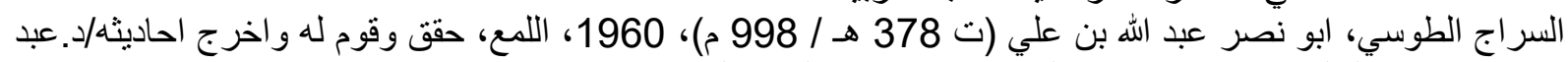

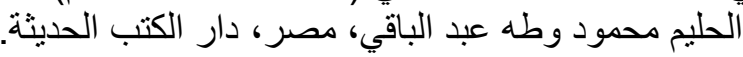

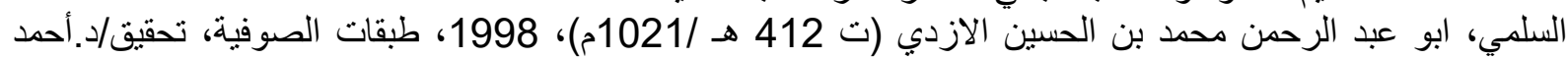

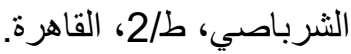

الصفدي، صلاح الدين خليل بن اييك (ت 764 هـ /1363 م)، 2000، الو افي بالوفيات، تحقيق/أحمد الارناؤوط وزكي

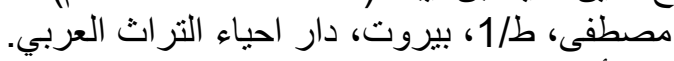

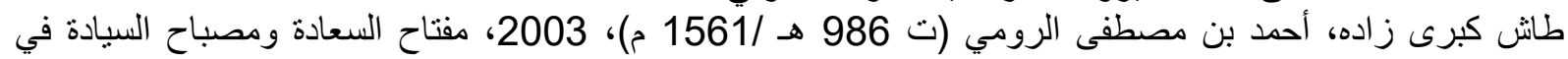

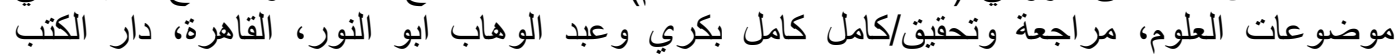

الحديثة. 


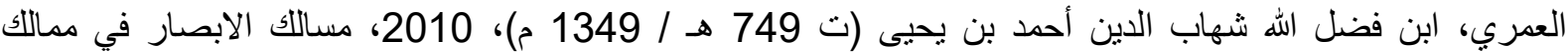

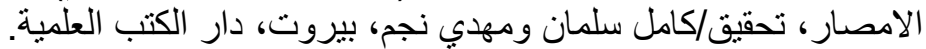

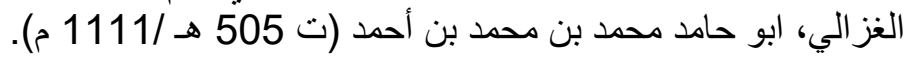

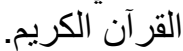

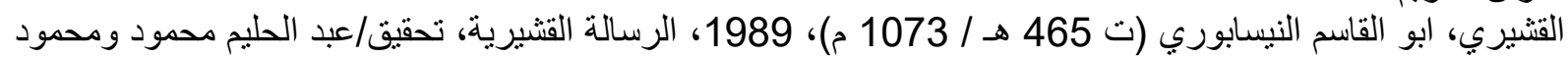
بن الثريف، القاهرة، مطابع مؤسسة الشعب الثب.

النعيمي، عبد القادر بن محمد الدمشقي (ت 927 هـ / 1521 م)، 2006، الدارس في تاريخ الددارس، تحقيق/جعفر الحسيني، ط/2/ القاهرة، مكتبة الثقافة الدينية.

ياقوت الحموي، شهاب الدين ابو عبد الله الرومي (ت 626 هـ / 1228 م)، 1957، معجم البلدان، بيروت، دار صادر.

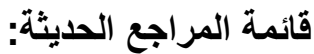

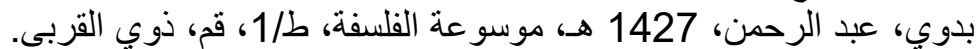

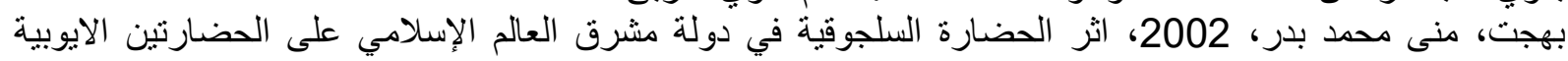

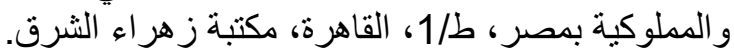

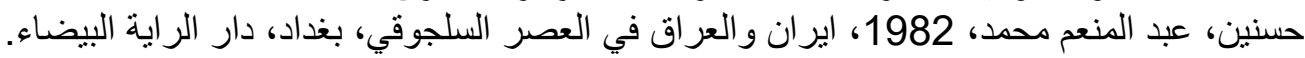

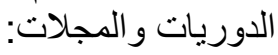

ديناني، غلام حسين ابراهيهي، 2004 م، المنطق و المعرفة عند الغزالي، تعريب/عبد الرحمن العلوي، ط/1، بيروت، دار الهادي للطبعة و النشر والتوزيع.

رمضانوف، ن.ف، 1980، دراسة في عالم الغزالي وفكره (1058-1111 م)، نرجمة وتقديم/د.جليل عماد الدين، مجلة/المورد، مجلد/التاسع، العدد/الر ابع، بغداد.

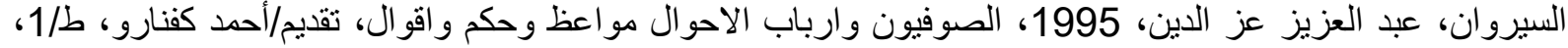

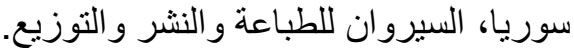

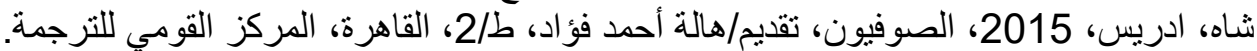

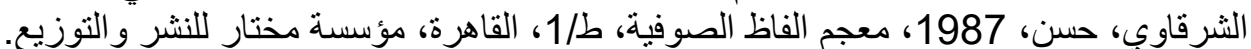

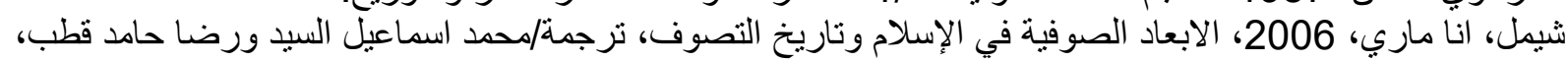

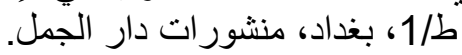

عبد القادر، محمد أحمد، بغداد، 2002، الفكر الإسلامي بين الإبنداعل والإن الابداع، الاسكندرية، دار المعرفة الجامعية.

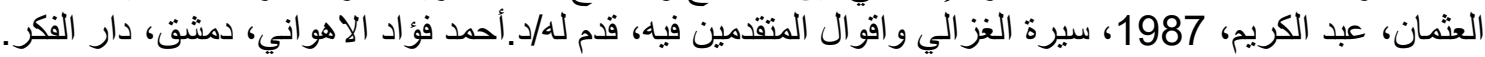

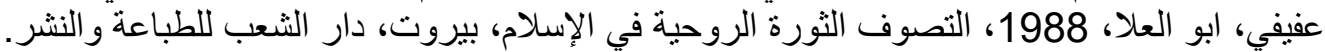

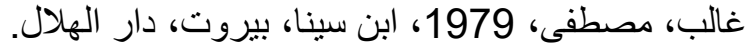

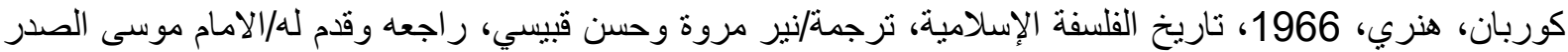

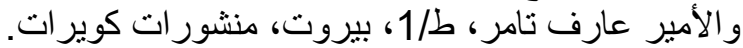

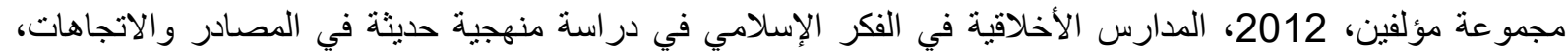

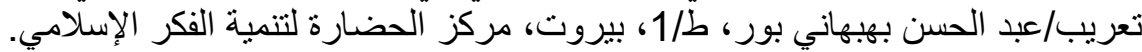

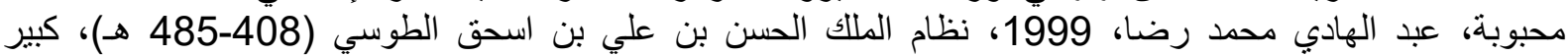

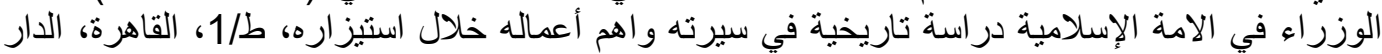

المصرية اللبنانية.

النشار، مصطفى، 1989، الغزالي ونظرية المعرفة، مجلة/عالم الفكر، مجلد/عشرون، العدد/الثالث، الكويت.

الهوامش:

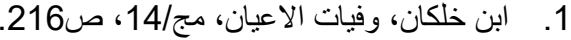

2

3.

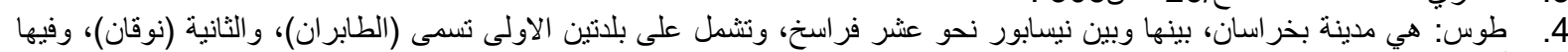

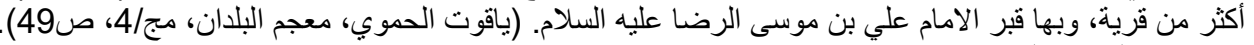

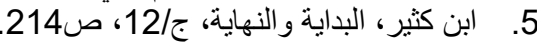

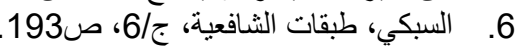
7 7. 8.

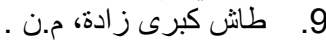




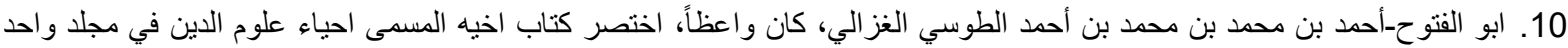
وسماه (لباب الاحباء)، وله تصنيف اخر سماه (الذخيرة في علم البصيرة)، خدم الصوفية بنفسه، وكان مائلا إلى الانقطاع والعزلة.

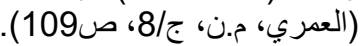

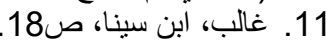

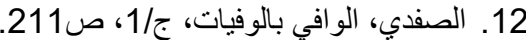

13. 13. التعليقة: أي انهُ دَون العلوم التني اخذها من اساتنته دون حفظ وتسميع.

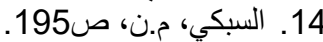

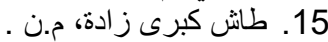

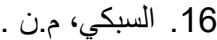

17. هو عبد الملك بن عبد الله بن يوسف بن محمد بن عبد الله بن حيويه النيسابوري، شيخ الثافعية، صاحب التصانيف. (الذهبي، سير اعلام

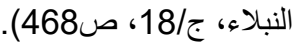

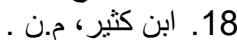

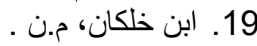

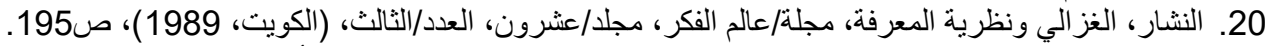

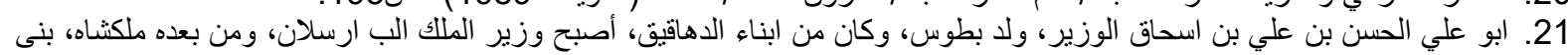

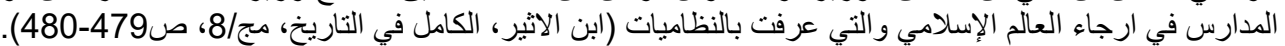

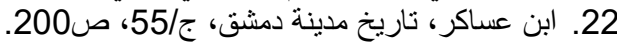

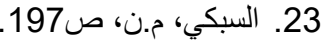

24. أي يعرض، افكار ومذهب الفيلاسفة، ثم بنتقد هذه الأراء فيما بعد.

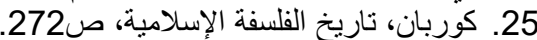

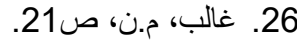

27. 27. ديناني، المنطق و والدعرفة عند الغزالي، صون.

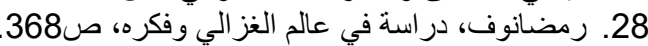

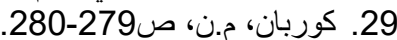

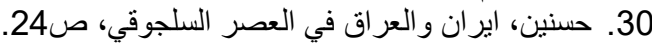

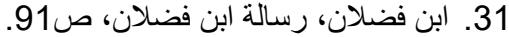

32. الراوندي، راحة الصدور وآية السرور في تاريخ الدولة الدئة السلجوقية، ص145.

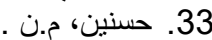

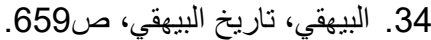

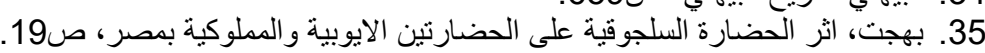

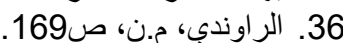

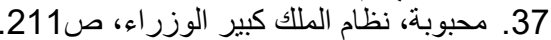

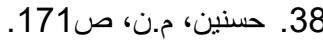

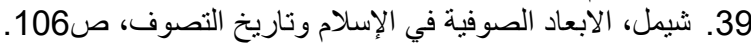

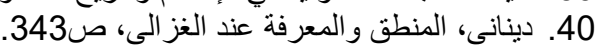

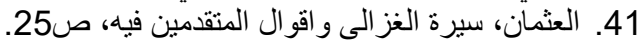

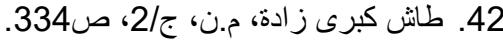

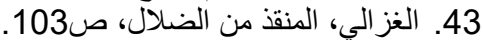

44. يذكر التز الي ان الغرض من الضُ الحج هو السفر إلى الثام بدون ان يطلع الخليفة على ذلك. ينظر : (طاش كبرى زادة، م.ن، ج/2، ص238).

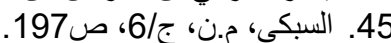

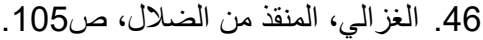

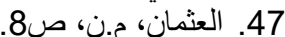

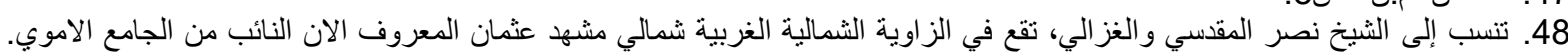

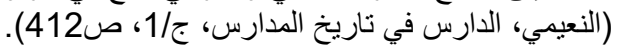

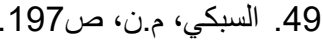

50. لم تؤكذ أكثر المصادر رحلته إلى مصر والاسكندرية، فأكثر الكتب تجاهلت هذه الرحلة، أو هي من نسج الخيال.

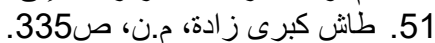

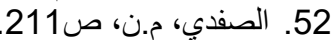

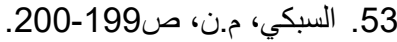

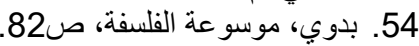

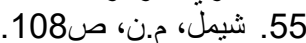

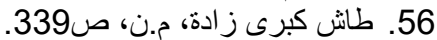

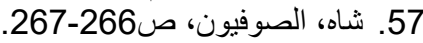

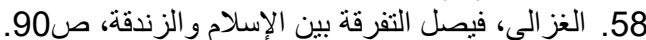

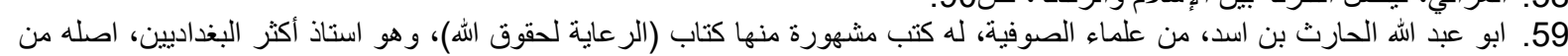

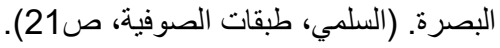




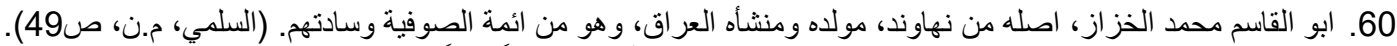

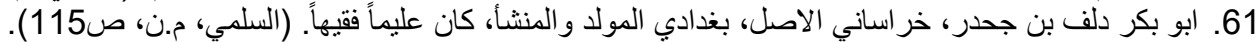

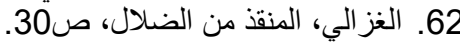

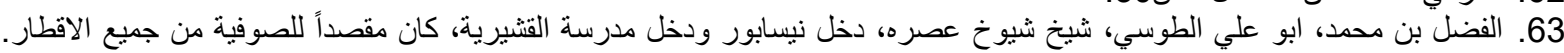

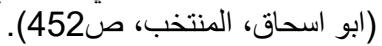

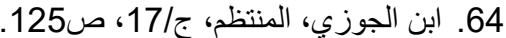

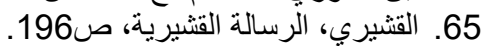

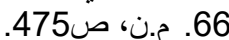

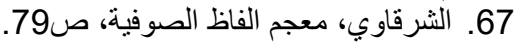

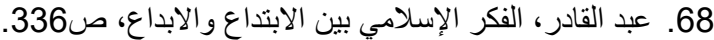

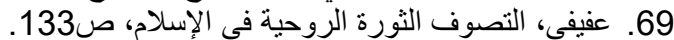

70.

71. ابو عبد الله محمد بن أحمد بن سالم، كان في البصرة ستين سنة، وهو من تلاميذ سهل التستري، واخذ الطريقة عنه. (الجامي، نفحات

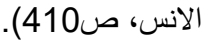

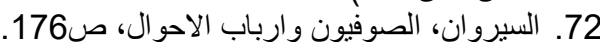

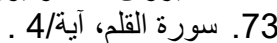

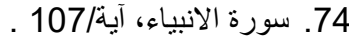

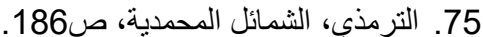

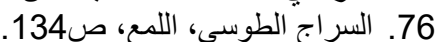

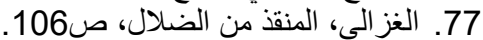

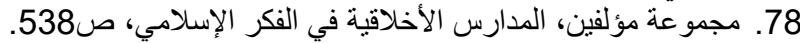

80

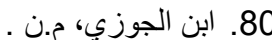

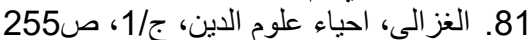

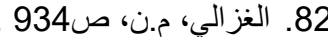

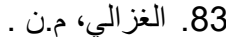

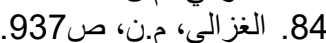

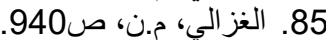

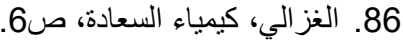

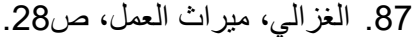

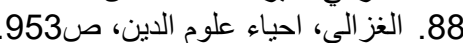

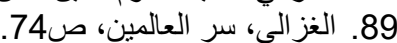

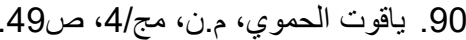

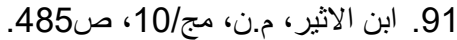

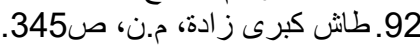

93. 92. م.ن، صنش كيري 